InVisible Culture • Issue 33: After Douglas Crimp

\title{
Contributors / Issue 33: After Douglas Crimp
}

\section{IVC Editors}

Published on: Jan 05, 2022

DOI: 10.47761/494a02f6.ed619d0d

License: Creative Commons Attribution 4.0 International License (CC-BY 4.0). 


\section{Articles}

Dr. Matthew Bowman lectures in fine art at the University of Suffolk and regularly writes art criticism for Art Monthly. His research focuses on twentieth century and contemporary art, criticism, and philosophy in the USA and Europe. He has authored numerous essays, many of which focus on the history of art criticism. In 2018 he published "Indiscernibly Bad: The Problem of Bad Art/Good Painting" in Oxford Art Journal and in 2019 "The Intertwining-Damisch, Bois, and October's Rethinking of Painting." A new essay, "Art Criticism in the Contracted Field" will be included in the next issue of the Journal of Aesthetics and Art Criticism. Currently, he is finishing editing an essay collection to be published as The Price of Everything and the Value of Nothing: Art Criticism and the Art Market for Bloomsbury and October and the Expanded Field of Art and Criticism for Routledge. www.essex.academia.edu/MatthewBowman

Theo Gordon received his PhD from The Courtauld Institute of Art in 2018, with a thesis on psychoanalysis and art of the American AIDS crisis. He has published in Art History, Oxford Art Journal, RA Magazine, Burlington Contemporary and The Conversation, and is Terra Foundation for American Art Postdoctoral Fellow at the Smithsonian American Art Museum for 2021.

Lutz Hieber is professor at the Institute of Sociology, Leibniz University Hanover, 1975-2010. Key focuses of his work include cultural sociology, media sociology, art sociology, political sociology, history of sociology, curating and lending material for exhibitions.

Gisela Theising is a vocational-school teacher and sociologist, director of the Color Technology and Interior Design Department of the Hanover Region Vocational School for Construction-Related Professions, BBS 3, 2004-2015, Vice Principal of the same since 2016. Additional professional activities include collecting, curating, and lending material for exhibitions covering psychedelic art of the 1960s and contemporary art from New York.

Christian Whitworth is a PhD Candidate in the Department of Art \& Art History at Stanford University. He specializes in modern and contemporary art, film, and media studies, and is currently writing a dissertation on postwar French expanded cinema and the aesthetics of speech-language impairment. His writing and criticism have appeared in publications like Millennium Film Journal, Afterimage: The Journal of 
Media Art and Cultural Criticism, and MAST: The Journal of Media Art Study and Theory.

\section{Artworks}

Cindy Hwang is an artist and designer living on unceded Lenape land (otherwise known as Brooklyn, New York). She currently works as a Brand Designer for Dashlane; her personal practice explores the relationship between politics and aesthetics. Originally from Phoenix, Arizona, she received a B.A. from Yale College in 2015 and an M.F.A. from the Yale School of Art in 2020. To see more of Cindy's work, please visit her website.

Hua Xi is a writer and artist. Their poems and paintings have appeared places like The American Poetry Review, The Nation and Boston Review. To learn more about Hua's practice, please visit their website.

\section{Dialogues}

Xiao (Amanda) Ju is a PhD Candidate in Visual and Cultural Studies at the University of Rochester. She writes about modern and contemporary art in China, international socialisms, (post-)socialisms, and feminist theories.

Peter Murphy is a PhD Candidate in Visual and Cultural Studies at the University of Rochester, where he is writing a dissertation that examines the relationship between figuration and queerness in modern and contemporary art. His art criticism has appeared in publications like The Brooklyn Rail and ASAP/J. He serves as the comanaging editor for InVisible Culture and as the director of the Hartnett Gallery.

Benjamin Haber is a Visiting Assistant Professor of Sociology at Wesleyan University, and has taught at Hunter College, New York University and Columbia University. Benjamin's work has been published in a variety of edited collections, magazines and journals, including Media, Culture \& Society, WSQ, Women \& Performance, boundary2, Real Life, and the volumes Digital Sociologies and Nonrepresentational Methodologies: Re-envisioning Research.

Daniel J Sander is an independent academic and curator with a $\mathrm{PhD}$ in Performance Studies from New York University. He has taught at New York University and Yale University and been a guest lecturer, critic, and/or reviewer at the Rhode Island School of Design, the International Center of Photography, Hunter College, University of Mississippi, New York University, Pratt Institute, Maple Terrace, Parsons School of 
Design, and the Wassaic Project. He was a 2019-2020 Curator-Mentor for CUE Art Foundation's Open Call.

Questionnaire

For more information on the questionnaire contributors, see each of their texts. 